\title{
Heart-rate recovery index in patients with chronic idiopathic urticaria
}

\section{Kronik idiyopatik ürtikerde kalp hızı toparlanma indeksi}

\author{
Emine ALTUNTAŞ ${ }^{1}$, Yasemin DOĞAN ${ }^{2}$, Feride ÇOBAN GÜL ${ }^{3}$, Hülya NAZiK ${ }^{4}$
}

\begin{abstract}
Heart rate recovery (HRR) index is a measure which shows indirectly autonomic cardiac function. In this study, it was aimed to investigate heart rate recovery index in patients with chronic idiopathic urticaria which is an inflammatory disorder. The study included 80 participants including 50 patients with chronic urticaria and 30 healthy individuals. All participants underwent treadmill exercise testing in compliance with Bruce protocol. There was no statistically significant difference between the groups included in the study when they were evaluated according to age, gender, fasting blood sugar, lipid profile, resting heart rate, systolic and diastolic blood pressures. All participants had normal 12-lead ECG result and demonstrated sinus rhythm during exercise test. All participants completed exercise testing without complication. Maximum heart rate and metabolic equivalent obtained by exercise stress test, heart rate recovery indices on 1., 2., 3 and 5. minutes were found to be similar in the patient and control groups ( $p>0.05)$. Heart rate recovery index is a marker for autonomic nervous system and it can be measured using treadmill exercise test. As a result of this study, it was determined that heart rate recovery index was not affected in patients with chronic idiopathic urticaria.
\end{abstract}

Keywords: Urticaria, heart rate recovery index, autonomic nervous system öz

Kalp hızı toparlanma indeksi (KHT) kardiyak otonomik işlevleri dolaylı olarak gösteren bir ölçüttür. Bu çalışmada, inflamatuvar bir hastalık olan kronik idiyopatik ürtikerli bireylerde KHT indeksi araştırılmak istendi. Çalışmaya 50'si kronik idiyopatik ürtiker, 30'u sağlıklı olmak üzere 80 olgu alındı. Tüm olgulara Bruce protokolü uygulanarak treadmill egzersiz testi yapıldı. Çalışmaya dahil edilen gruplar yaş, cinsiyet, açlık kan şekeri, lipid profili, istirahat kalp hızı, sistolik ve diyastolik kan basıncı açısından değerlendirildiğinde aralarında istatistiksel olarak anlamlı bir fark yoktu. Tüm katılımcılardan istirahat sırasında elde edilen 12 derivasyonlu EKG normal ve hepsi egzersiz testi boyunca sinüs ritmindeydi. Katılımcılar egzersiz testini komplikasyonsuz tamamladı. Ürtikerli grup ile kontrol grubu, egzersiz stres testi ile elde edilen maksimal kalp hızı, metabolik eşdeğereleri ve birinci, ikinci, üçüncü ve beşinci dk.'daki KHT indeksleri açısından değerlendirildiğinde, aralarında anlamlı bir fark görülmedi ( $p>0,05)$. Kalp hızı toparlanma indeksi; otonomik sinir sisteminin bir göstergesidir ve treadmill egzersiz testi ile ölçülebilir. Bu çalışma sonucunda, kronik idyopatik ürtikerli bireylerde KHT indeksinin etkilenmediği görülmüştür.

Anahtar kelimeler: Ürtiker, kalp hızı toparlanma indeksi, otonom sinir sistemi

\section{INTRODUCTION}

Urticaria that can be either acute or chronic, is a disorder characterized by raised, itchy, erythematous papules and plaques which can regress spontaneously. In general, lesions are regressed within a few hours to 24 hours without any defect ${ }^{1}$. Chronic idiopathic urticaria is defined as persistence of urticaria for more than 6 weeks, which progresses with recurrence of urticaria lesions almost daily without any identifiable etiologic factor ${ }^{2}$. Although its actual prevalence is unknown, it has been reported that it is seen in at least $0.1 \%$ of the patients with a prevalence up to $3 \%^{3}$.

Mast cells play a key role in the pathogenesis of urticaria. Degranulation occurs by activation of mast cells via immunological and non-immunological path-

Received: 10.07 .2017

Accepted: 29.08 .2017

1Zonguldak Atatürk State Hospital, Department of Cardiology, Zonguldak, Turkey

2Kayseri Educational And Research Hospital, Departmant of Cardiology, Kayseri, Turkey

3Elazığ Educational Research Hospital, Department of Dermatology, Elazig, Turkey

4Kahramanmaraş Sütçü Imam Universty Mediccal Faculty, Department of Dermatology, Kahramanmaraş, Turkey

Yazışma adresi: Emine Altuntas, Zonguldak Atatürk State Hospital, Department of Cardiology, Zonguldak, Turkey

e-mail: emine_altuntas@hotmail.com 
ways. This leads to release of potent inflammatory mediators including histamine, leukotrienes (LTS), prostaglandins (PGs), platelet activating factor (PAF), kallikrein-like enzymes, anaphylatoxins (C3a, C4a and C5a), bradykinin and cytokines. These factors cause itching, increased vascular permeability and tissue edema $^{4-7}$.

Alterations in heart rate during exercise or recovery period after exercise are determined by balance between sympathetic and vagal activities. The sympathetic activity that is heightened during exercise period is reduced while parasympathetic activity is re-heightened in the recovery period after exercise, resulting in decreasing heart rates ${ }^{8}$. Heart-rate recovery (HRR) index is calculated by subtracting heart rates at $1 ., 2$. and 3 . minutes during recovery period from maximum heart rate in the patients undergoing submaximal or maximal exercise testing ${ }^{9}$.

It has been reported that decrease in the early phase of recovery period is associated with parasympathetic system while decrease in subsequent period is associated with abolishment of effects of sympathetic system $^{10}$. It was reported that elevated sympathetic activity increases mortality rates by disrupting hemodynamic mechanisms ${ }^{11}$. It is shown that decreased HRR index is an independent risk factor for cardiovascular mortality ${ }^{12,13}$.

In recent years, the interaction between immune system and peripheral nervous system in skin has attracted much attention and epidermis is considered as a sensory organ ${ }^{14}$. In this interaction, Langerhans and mast cells play a key interactive role between neuroendocrine and immune systems ${ }^{15}$.

Neuroendocrine stress response is provided by hypothalamic-pituitary-adrenal (HPA) axis and autonomic nervous system. It was reported that immune regulation is disrupted under stress due to impaired HPA axis in chronic inflammatory cutaneous disea$\operatorname{ses}^{16}$.

In this study, it was aimed to investigate the usability of heart-rate recovery index in patients with a cardiovascular risk factor and chronic idiopathic urticaria which is an inflammatory disease with acute phase responses and.

\section{MATERIAL and METHODS}

The study population consisted of 80 participants applied to the dermatology policlinic of the hospital. Fifty participants had chronic idiopathic urticaria disease and the remaining 30 subjects were healthy controls. Participants' ages ranged from 15 to 70 years. Approval of the local ethics committee was obtained. All participants were informed about the study and got informed consent forms. The present study was conducted between June, 2015 and September, 2015. The diagnosis of chronic idiopathic urticaria was based on clinical manifestations, and skin lesions. The echocardiography and baseline ECG were evaluated in all participants and results of these tests were within normal range. In the two groups also, there were no cardiovascular or other systemic diseases, such as coronary artery disease, valve disease, heart-renal-liver failure, arrhythmia, hypertension, anemia, diabetes mellitus, and inducible urticaria.

The stress test complying with the Bruce protocol which aims to reach age-specific maximum heart rate was performed on all participants to calculate heart rate recovery index. During this test it was aimed to reach maximum heart rate or minimum \%85 percent of this rate. Maximum heart rate was calculated using the following formula:

Maximum heart rate $=220$ - patients' age .

During this test ECG tracings were recorded continuously. Participants were brought to rest in supine position during 5 minutes after completion of the test and heart rates were continually recorded. Heart rate recovery indices (HRR1, HRR2, HRR3 and HHR5) were calculated by using measurements of heart rates at 1., 2., 3. and 5. minutes during recovery period. 


\section{Statistical analysis}

Continuous variables were presented as mean \pm standard deviation and categorical variables as percentages. The Kolmogorov-Smirnov test was used to determine whether the variables were in normal distribution. The Student's t test was used to compare the continuous variables of the two groups and Mann-Whitney $U$ test was used for nonparametric values. Chi-square test was used to compare categorical data, and values of $p<0.05$ were considered to be statistically significant.

\section{RESULTS}

Baseline clinical characteristics of chronic idiopathic urticaria and control groups are presented in Table 1. There was no significant difference between the 2 groups regarding age, sex and resting pulse rates. Total cholesterol, LDL-cholesterol, triglyceride and creatinine levels were similar between the groups. Mean duration of disease was 11.1 months. All patients and healthy controls completed the exercise stress tests without having difficulty. Both groups reached at least $85 \%$ of the predicted maximum heart rates. The duration of exercise, maximum heart rates, and percentage of maximum heart rates reached during peak exercise were similar in both groups. Heart-rate recovery indices at $1 ., 2$., 3 . and 5 . minutes during re-

Table 1. Baseline demographic and clinical characteristics of cronic idiopathic urticarial and control groups.

\begin{tabular}{|c|c|c|c|}
\hline & $\begin{array}{l}\text { Chronic idiopathic } \\
\text { urticarial group } \\
n=50\end{array}$ & $\begin{array}{l}\text { Control } \\
\text { group } \\
n=30\end{array}$ & p* \\
\hline Age (years) & $35,7 \pm 11,7$ & $37 \pm 11$ & 0,624 \\
\hline Total cholesterol (mg/dl) & $179,7 \pm 32,6$ & $179,5 \pm 15,5$ & 0,968 \\
\hline LDL-C (mg/dl) & $109 \pm 26,2$ & $116,9 \pm 11,7$ & 0,069 \\
\hline Triglycerides (mg/dl) & $135,3 \pm 71,7$ & $164,8 \pm 65,1$ & 0,063 \\
\hline Creatinine level (mg/dl) & $0,8 \pm 0,1$ & $0,8 \pm 0,1$ & 0,680 \\
\hline Hemoglobin (g/dl) & $13,9 \pm 1,3$ & $13,5 \pm 1,2$ & 0,159 \\
\hline $\begin{array}{l}\text { Resting Pulse } \\
\text { (beat/minute) }\end{array}$ & $78,1 \pm 10,6$ & $76,6 \pm 8,4$ & 0,471 \\
\hline
\end{tabular}

LDL-C:Low density lipoprotein cholestrol

*Student's $t$ test was used to compare continuous variables between 2 groups.

$p<0.05$ was considered as significant. covery period were similar in the patient and control groups (Table 2).

Table 2. Exercise stress test parameters of chronic idiopathic urticarial and control groups.

\begin{tabular}{|c|c|c|c|}
\hline & $\begin{array}{l}\text { Chronic idiopathic } \\
\text { urticarial group } \\
n=50\end{array}$ & $\begin{array}{l}\text { Control } \\
\text { group } \\
n=30\end{array}$ & p* \\
\hline Duration (minute) & $14,02 \pm 1,48$ & $14,27 \pm 1,43$ & 0,452 \\
\hline Maximum HR (bpm) & $159,8 \pm 9,9$ & $161 \pm 16,3$ & 0,710 \\
\hline HRR1 & $22,7 \pm 9,3$ & $24 \pm 6,6$ & 0,429 \\
\hline HRR2 & $37,7 \pm 10,2$ & $41,5 \pm 8,9$ & 0,098 \\
\hline HRR3 & $43,8 \pm 10,5$ & $48,4 \pm 10,6$ & 0,071 \\
\hline HRR5 & $48,7 \pm 10,4$ & $52,9 \pm 11,9$ & 0,084 \\
\hline
\end{tabular}

HR: Heart rate

HRR1, HRR2, HRR3HRR5: Heart rate recovery indexes (heart rates on minute 1, 2, 3 and 5 during recovery period)

*Student's $t$ test was used to compare continuous variables between 2 groups.

$p<0.05$ was considered as significant.

\section{DISCUSSION}

In this study, heart-rate recovery indices at 1., 2., 3. and 5 . minutes measured by maximal exercise testing were compared between patients with chronic idiopathic urticaria and healthy controls. The primary reason for decreased heart rate after exercise is an increase in vagal activity during recovery period. The sympathetic activity that is heightened during exercise period is reduced while parasympathetic activity is re-heightened in the recovery period after exercise, resulting in decreased heart rate ${ }^{17}$. It was found that the extent of decrease on minute one was inversely correlated with mortality. If this decrease is high, the risk of cardiovascular mortality is also low ${ }^{9}$. Sympathetic hyperactivity increases cardiovascular load and hemodynamic stress and makes patient vulnerable to endothelial dysfunction, coronary artery spasm, left ventricular hypertrophy, severe arrhythmias, stroke and cardiac mortality ${ }^{18}$. In contrast, increased parasympathetic activity reduces blood pressure and heart rate and prevents ischemic arrhythmias ${ }^{19}$.

In recent years, a relationship has been determined between inflammatory diseases and heart-rate recovery index. The heart-rate recovery index was evaluated in Familial Mediterranean Fever, Behcet's Di- 
sease, Systemic Lupus Erythematosus, and Psoriasis. Consequently, lower heart rate recovery indices were determined in patient groups than control groups ${ }^{20-23}$. In many studies, it was shown that decreased heartrate recovery index after exercise is an independent risk factor for cardiovascular and all-cause mortality in healthy individuals ${ }^{21-24}$.

In chronic idiopathic and even in physical urticaria, either psychological or emotional stress can have partial contribution to promoting factors through hypothalamic-vascular axis. In addition, they can play a role as amplifier after onset of reaction. Emotional stress impairs cytokine/histamine balance through hypothalamic neuropeptides and causes degranulation and release of vasoactive-inflammatory substances by stimulating cutaneous mast cells ${ }^{25,26}$. It is thought that it is associated with increased plasma cortisol levels due to hyperactivation of this axis ${ }^{27}$ and high plasma cortisol levels are associated with cardiovascular diseases leading to diabetes mellitus, hypercholesterolemia, hypertriglyceridemia, elevated blood pressure and obesity components of metabolic syndrome ${ }^{28}$. Hyperactivity of HPA axis leads to increased activity of sympathoadrenal system and plasma catecholamine levels through central regulatory mechanisms. Increased plasma catecholamines exert adverse effects on cardiovascular system by leading to vasoconstriction, platelet activation and tachycardia $^{29}$. Skin plays neuroendocrine role to maintain equilibrium between internal and external environments. This neuroendocrine function occurs through interplay between nervous and immune systems. Neuromediators released from sensorial and autonomic nerve fibrils affect inflammatory reaction cascade by binding receptors present in cutaneous and immune cells ${ }^{30}$. It was found that inflammation plays a role in all stages from onset and progress to development of thrombotic complications of an atherosclerotic event ${ }^{31}$. Predictive value of inflammatory markers for potential cardiovascular events in the future has been shown in patients with stable angina, unstable angina and history of acute myocardial infarction ${ }^{32}$.

This study was designed to investigate the role pla- yed by inflammation and HPA axis in the etiopathogenesis of cardiovascular mortality and urticaria. Based on our results, no significant difference was observed between patient and control groups as for 4 variables evaluated which may be due to lack of precise information about the level of inflammation and autonomic dysfunction in which heart-rate recovery index was decreased. In addition, mean values of 4 variables evaluated were found to be lower in the patient group when compared with the controls but the difference did not reach statistical significance. This suggests that significant difference can be observed in future studies conducted with larger sample size.

In the etiology of urticaria, many factors have been identified. In acute urticaria, the most important etiologic factors are drugs, foods and infections. However etiology in chronic urticaria is mostly unknown. In $50 \%$ of chronic urticaria patients, the cause can not be identified. For its clarification, etiology should be identified via a detailed anamnesis. With detailed anamnesis, it has been reported that in $72-86 \%$ of the patients the etiologic factor may be identified. The other cause of not having a meaningful relationship between the groups in this study may be that patients were not divided into groups etiologically, because it was thought that all chronic urticaria types could not activated HPA axis ${ }^{33,34}$.

\section{Study limitations}

In this study, the most important limitation was our relatively small sample size.

\section{REFERENCES}

1. Kaplan AP. Urticaria andangioedema. In: Adkinson NF, Yunginer JW, Busse WW editors. Allergy principle sand practice. $6^{\text {th }}$ ed. St. Louis, Missouri: Mosby-YearBooklnc, 2003: 1537-59.

2. Sabroe RA, Greaves MW. The pathogenesis of chronic idiopathic urticaria. Arch Dermatol 1997;133:1003-1008. https://doi.org/10.1001/archderm.1997.03890440085013

3. Kaplan AP. Urticaria and angioedema. Middleton E, Reed CE, Ellis EF et al editors. Allergy Principles and Practice. 5. baskı. 1998: 1104-1122.

4. Maurer M, Bindslev-Jensen C, Gimenez-Arnau A, et al. Chronic idiopathic urticaria is no longer idiopathic: time for an update! Br J Dermatol 2013;168:455-6. https://doi.org/10.1111/j.1365-2133.2012.11171.x 
5. Zuberbier T, Aberer W, Asero R, et al. The Guideline for the definition, classification diagnosis and management of urticaria: the 2013 revision and update. Allergy 2014;69:868-87. https://doi.org/10.1111/all.12313

6. Bernstein J, Lang D, Khan D, et al. The diagnosis and management of acute and chronic urticaria. J Allergy Clin Immunol 2014;133:1270-7. https://doi.org/10.1016/j.jaci.2014.02.036

7. Kaya Ti, Akyol A. Ürtiker patogenezi: Kronik idiyopatik ürtiker patogenezi konusundaki gelişmeler. Türkiye Klinikleri Dermatoloji Dergisi 1999;9(1):41-50.

8. Javorka M, Zila I, Balharek T, et al. Heart rate recovery after exercise: relations to heart rate variability and complexity. Braz J Med Biol Res 2002;35:991-1000. https://doi.org/10.1590/S0100-879X2002000800018

9. Morshedi-Meibodi A, Larson MG, Levy D, et al. Heart rate recovery after treadmill exercise testing and risk of cardiovascular disease events (The Framingham Heart Study). Am J Cardiol 2002;90:848-52. https://doi.org/10.1016/S0002-9149(02)02706-6

10. Sears CE, Choate JK, Paterson DJ. Inhibition of nitricoxide syntases lows heart rate recovery from cholinergic activation. J Apll Physiol 1998;84(5):1596-603.

11. Higgins JP, Higgins JA. Electrocardiographic exercise stres testing: An up date beyond the ST segment. Int J Cardiol 2007;116(3):285-99. https://doi.org/10.1016/j.ijcard.2006.04.047

12. Palatini P. Heart rate as an independent risk factor for cardiovascular disease: current evidence and basic mechanisms. Drugs 2007;67(2):3-13. https://doi.org/10.2165/00003495-200767002-00002

13. Perret-Guillaume $C$, Joly L, Benetos A. Heart rate as a risk factor for cardiovascular disease. Prog Cardiovasc Dis 2009;52(1):6-10. https://doi.org/10.1016/j.pcad.2009.05.003

14. Boulais N, Misery L. The epidermis: a sensory organ. Eur J Dermatol 2008;18:119-27.

15. Misery L. Langerhans cells in the neuroimmunocutaneous systemic J Neuroimmuno-cutaneoussystem. J Neuroimmunol 1998;89:83-7. https://doi.org/10.1016/S0165-5728(98)00117-9

16. Buske-Kirschbaum A, Hellhammer DH. Endocrine and immune responses to stress in chronic inflammatory skin disorders. Acad Sci 2003;992:231-240. https://doi.org/10.1111/j.1749-6632.2003.tb03153.x

17. Savin WM, Davidson DM, Haskell WL. Autonomic contribution to heart rate recovery from exercise in humans. J Appl Physiol 1982;53:1572-5.

18. Higgins JP, Higgins JA. Electrocardiographic exercise stres testing: An update beyond the ST segment. Int J Cardiol 2007;116:285-99. https://doi.org/10.1016/j.ijcard.2006.04.047

19. Curtis BM, O'Keefe JH. Autonomic tone as a cardiovascular risk factor: The dangers of chronic fight or flight. Mayo Clin Proc 2002; 77:45-54. https://doi.org/10.4065/77.1.45
20. Ardic I, Kaya MG, Yarlioglues M, et al. Assessment of heart rate recovery index in patients with Familial Mediterranean Fever. Rheumatol Int 2011;31(1):121-5. https://doi.org/10.1007/s00296-010-1550-y

21. Kaya EB, Yorgun $H$, Akdogan $A$, et al. Heart-rate recovery index is impaired in Behçet's disease. Tex Heart Inst J 2009;36(4):282-6.

22. Dogdu O, Yarlioglues M, Kaya MG, et al. Assessment of atrial conduction time in patients with systemic lupus erythematosus. J Investig Med 2011;59(2):281-6. https://doi.org/10.2310/JIM.0b013e318207050a

23. Sarli B, Dogan Y, Baktir AO, et al. Heart rate recovery is impaired in patients with psoriasis. Med Princ Pract 2013;22:56770. https://doi.org/10.1159/000351884

24. Nishime EO, Cole CR, Blackstone EH, et al. Heart rate recovery and treadmill exercise score as predictors of mortality in patients referred for exercise ECG. JAMA 2000;284(11):1392-8. https://doi.org/10.1001/jama.284.11.1392

25. Guillet G, Garcia C, Guillet MH. Urticaire et psychisme: duconstat cliniqueaux neuropeptides. Revue Francaised' Allergologie et d'Immunologie Clinique 1998;38:401-4. https://doi.org/10.1016/S0335-7457(98)80062-2

26. Singh LK, Pang $X$, Alexacos N, et al. Acute immobilization stres triggers skin mast cell degranulation via corticotropin releasing hormone, neurotensine and substance $P$ : a link to neurogenic skin disease. Brain, Behaviour and Immunity 1999;13:225-39. https://doi.org/10.1006/brbi.1998.0541

27. Deuschle M, Weber B, Colla M, et al. Effects of major depression, aging and gender upon calculated diurnal free plasma cortisol concentrations: a re-evaluation study. Stress 1998;2:281-7. https://doi.org/10.3109/10253899809167292

28. Rosmond R. Role of stress in the pathogenesis of the metabolic syndrome. Psychoneuroendocrinology 2005;30:1-10. https://doi.org/10.1016/j.psyneuen.2004.05.007

29. Remme WJ. The sympathetic nervous system and ischaemic heart disease. Eur Heart J 1998;19:62-71.

30. El-Nour H, Lundeberg L, Boman A, et al. The expression and functional significance of the serotonin-2C receptor in murine contact allergy. Exp Dermatol 2007;16:644-50. https://doi.org/10.1111/j.1600-0625.2007.00573.x

31. Frohlich ED. Potential mechanisms explaining the risk of left ventricular hypertrophy. Am J Cardiol 1987;59(2):91-7. https://doi.org/10.1016/0002-9149(87)90183-4

32. Novo S, Abringnani MG, Corda $M$, et al. Cardiovascular structural changes in hypertension: possible regression during long-term antihypertensive treatment. Eur Heart $J$ 1991;12(Suppl G):47-52.

33. Göncü EK, Aktan Ş, Atakan N, et al. The Turkish Guideline for the Diagnosis and Management of Urticaria-2016. TurkdermArch Turk Dermatol Venerology 2016;50:82-98.

34. Erdem T. An Approach to the Patient of Urticaria. Turk J Dermatol 2014;3:178-82. 